\title{
Reading Ability, Reading Fluency and Orthographic Skills: The Case of L1 Slovene English as a Foreign Language Students
}

Florina ERbeli ${ }^{* 1}$ AND KARMEn PižORN ${ }^{2}$

$\approx \quad$ This study examined the difference between less-skilled and skilled L1 Slovene English as foreign language (EFL) students in foreign language (L2) fluency and L2 orthographic skills; 93 less-skilled Grade 7 L1 Slovene students and 102 skilled Grade 7 L1 Slovene students participated in the study. The results showed that skilled readers performed better in all fluency and orthographic skills tasks, as the differences between groups were statistically significant. The correlations among all variables showed that L2 fluency and L2 orthographic skills are positively interrelated among both groups, suggesting that higher L2 fluency scores are associated with higher L2 orthography scores. This outcome implies that less-skilled readers need to be greatly exposed to L2 language and be ensured necessary opportunities in- or outside the classroom in L2 learning.

Keywords: reading fluency, orthographic skills, English as a foreign language, Slovene skilled and less-skilled readers 


\section{Bralna spretnost, tekočnost branja in pravopisne spretnosti pri tujem jeziku - angleščini - pri slovenskih učencih}

Florina ERbeli* In Karmen Pižorn

$\propto$ V raziskavi so proučevane razlike med skupino bralno manj usposobljenih (J1) in skupino bralno usposobljenih (J1) slovenskih učencev glede bralne spretnosti, tekočnosti branja in pravopisnih spretnosti pri angleščini (J2). Sodelovalo je 93 bralno manj usposobljenih (J1) in 102 bralno usposobljena (J1) učenca sedmega razreda. Izsledki kažejo, da je skupina bralno usposobljenih učencev v primerjavi s skupino bralno manj usposobljenih učencev dosegla boljši izid pri vseh nalogah, ki so merile bralno spretnost, tekočnost branja in pravopisne spretnosti v J2. Razlike med skupinama so bile statistično pomembne. Poleg tega koeficienti korelacij med vsemi spremenljivkami pri obeh skupinah kažejo, da tekočnost branja in pravopisne spretnosti v J2 pozitivno korelirajo; višji izid pri nalogah tekočnosti branja je povezan $z$ višjim izidom pri nalogah, ki merijo pravopisne spretnosti. Ta ugotovitev je pomembna predvsem za bralno manj usposobljene učence. Za izboljšanje njihove tekočnosti branja in pravopisnih spretnosti morajo biti deležni dovolj velikega vnosa J2, zato jim je treba zagotoviti možnosti za učenje J2 v razredu in zunaj njega.

Ključne besede: tekočnost branja, pravopisne spretnosti, tuji jezik angleščina, bralno manj usposobljeni učenci, bralno usposobljeni učenci 


\section{Introduction}

People learn to read their first language (L1) in a wide variety of circumstances. Children are prepared for reading at an early age by listening to stories, being read to, and interacting with adults and others about the stories they hear. When children start to learn to read in their L1, they already have a large vocabulary, good control of the grammar of the language, have had many stories in that language read to them, and know the discourse (Nation, 2009). However, when these children start to read in a foreign language, i.e. L2 (or English in this study), learning to read in an L2 involves a great deal of language learning. Unlike in their $\mathrm{L}_{1}$, in the L2 learning, oral language and literacy competencies develop simultaneously. Children need grammatically and lexically controlled texts, a greater amount of pre-reading activities; they have to learn a different orthographic system; and they need to process the meaning of words while trying to achieve the same main goal of reading as in L1: text comprehension. All these principles draw on one's cognitive resources (capacity of working memory) that are limited at any given moment; therefore, by learning to read quickly, accurately, i.e. fluently, and not thinking about orthography, vocabulary and syntax, sufficient mental resources become available for higher-level processes, such as overall reading performance and reading comprehension. Reading fluency has been associated with reading comprehension in English L1 contexts (Fuchs, Fuchs, Hosp, \& Jenkins, 2001); however, simply applying the findings from $\mathrm{L}_{1}$ research to the case of $\mathrm{L}_{2}$ readers is inadequate. The nature of L2 reading development is different from that of L1. L2 reading fluency alone does not account for the variance of explaining reading performance in L2. Diverse abilities reading in one's own $\mathrm{L}_{1}$, distance between $\mathrm{L}_{1}$ and $\mathrm{L}_{2}$ orthographic systems, L2 vocabulary knowledge, cognitive measures, and metalinguistic awareness affect reading performance in L2 (Koda, 2010). Nonetheless, fluency explains significant variance in reading ability (Hoover \& Gough, 1990) and problems in acquiring word-level and contextual-level reading are the principal difficulties faced by children who encounter reading problems (Grabe, 2009). However, when reading in an L2, the distance between L1 and L2 writing systems also plays a significant role in word recognition, and consequently on text comprehension (Koda, 2010).

As L2 reading performance relates to a number of processes and differs among different reading groups, research needs to consider the relationship between skills and their interaction, impact of each skill on L2 reading performance, and differences among groups to obtain a comprehensive explanation of $\mathrm{L}_{2}$ reading. L2 reading-fluency research related to L2 orthographic skills 
must attempt to discover regularities observed between different reader groups. This study attempted to investigate precisely that. Identifying fluency patterns and orthographic skills associated with L1 Slovene readers has implications for teaching, since these findings can lead to a model that will help determine common deficiencies and limitations characterizing less-skilled readers and thereby contribute to providing appropriate reading strategies.

\section{Research on L2 Reading Fluency}

Skills in reading processing such as word recognition play a significant role in learning to read in an L2. Inefficiency conducting those skills can lead to reading being a slow and difficult process (Anderson, 1999; Segalowitz, Poulsen, \& Komoda, 1991). It may even lead to a decrease in motivation for reading. L2 reading is for most readers the major input and experience source for learning an L2 (Redfield, 1999) and less-skilled readers run the danger of becoming caught in the vicious circle of reading less leading to understanding less leading to not enjoying reading and speaking in an L2 (Nuttall, 1996) if they do not focus much more attention on word-level development of automaticity at the early stages of reading in L2. Fluency, i.e. word recognition and speed, is what allows a reader to expand the breadth and depth of vocabulary knowledge beyond direct instruction, to develop automatic word recognition skills, and to build reading motivation. Moreover, fluency is one of the keys to L2 learning outside the classroom (Grabe, 2009). For these reasons, fluency must be a curricular and instructional goal for reading development.

In examining research on L2 reading fluency, there are far fewer studies compared to those on L1. The impact of word recognition skills and passage reading ability on reading comprehension has been examined in a few L2 group comparison studies. Verhoeven (2000) and Droop and Verhoeven (2003) have determined a significant causal relationship between word recognition skills and reading comprehension measures. Shiotsu (2010) has investigated the relationship between L2 word recognition and reading ability. Faster processing of meaning characterized word recognition by the more skilled readers, and the less-skilled readers were slower in accessing meaning. Segalowitz (2000) reviews his early research (Favreau \& Segalowitz, 1982; Segalowitz, 1986; Segalowitz, Poulsen, \& Komoda, 1991) on advanced L2 readers to show that fluency can be a major factor in advanced $\mathrm{L}_{2}$ reading abilities.

The primary pedagogical implication drawn by Segalowitz (2000) is that word-recognition fluency can be developed through extensive repetitions of appropriate input in conditions that nearly match the initial learning in order 
for fluency and automaticity to develop. Other training studies include research by Akamatsu (2008) and Fukkink, Hulstijn and Simis (2005). Results have shown that training improved students' word-recognition performance in both speed and accuracy. In the case of Fukkink, Hulstijn and Simis (2005), the results show that training over two sessions improved reading rates; however, a significant improvement in reading comprehension after two days of word recognition training was not determined. Taguchi and colleagues (Gorsuch \& Taguchi, 2008; Taguchi, Takayasu-Maass, \& Gorsuch, 2004) have demonstrated that a training program of silent repeated reading practice will significantly improve not only reading rates but also reading comprehension.

While the studies reviewed above examined more mature, literate readers, Geva, Wade-Wooley, and Shany (1997) focused on younger students learning to read simultaneously in English (L1) and Hebrew (L2). They concluded that steps associated with the development of L1 reading efficiency (i.e., accuracy attained before speed) are applicable to the development of word recognition skills in L2, but they do not emerge concurrently in both languages. The authors also concluded that specific linguistic features such as orthographic depth and morphosyntactic complexity may interact with more global L2 proficiency effects in determining the course of $\mathrm{L}_{2}$ reading skills development.

Overall, the L2 fluency research, while limited in number of studies, generally supports the importance of word and contextual reading fluency and training on reading comprehension improvements. Before taking up the question of the orthography system of Slovene language differing from that of an L2, and L2 orthography skills relating to reading fluency of L2 between different groups, we briefly consider current understanding of word and contextual reading fluency.

\section{Word and Contextual Reading Fluency}

Although word-level reading skill can be measured in or out of the context, the two are not identical. For one thing, words in context are read faster than the same words out of context (Stanovich, 1980). Contextual reading fluency is influenced not purely by context-free word recognition, but also by processes that originate in context.

The relation between context facilitation of word recognition and reading ability has been a controversial topic. After Goodman's proposal (1976) that skilled readers made greater use of context for word identification compared to poor readers, Stanovich (1980) presented an interactive-compensatory model to explain individual differences in reading fluency. According to this model, 
bottom-up (print driven) and top-down (meaning driven) processes operate concurrently when a word is encountered in sentence context. Whether individuals rely on context to expedite word recognition depends on the efficiency of their bottom-up processes. Skilled readers rarely depend on conscious prediction to identify words in context, because their word identification processes operate extremely fast, before the relatively slow, hypothesis-forming (topdown) processes conclude their work. In fact, as individuals grow in reading ability, word identification becomes so rapid as to be described as encapsulated (i.e., impenetrable by outside knowledge sources or conscious prediction; Stanovich, 1991). In contrast, less-skilled readers are burdened by inefficient word-processing skills that execute even more slowly than top-down word prediction processes. Sentence context compensates for poor readers' slow print processing when it delivers top-down information about a word's identity before bottom-up processing has concluded.

Both perspectives, nevertheless, share the assumption that efficient word recognition in isolation or in context frees up capacity for higher level, integrative comprehension processing of text.

\section{Research on L2 Orthographic Skills}

Transfer is a major concern in second language acquisition research. A considerable number of studies have shown systematic L1 influences on virtually all aspects of L2 learning and processing, including on orthography (Fashola, Drum, Mayer, \& Kang, 1996). In order to examine the cross-linguistic impacts of L1 influences on L2 orthographic skills, it is vital to clarify how previously learned reading sub-skills, such as orthographic skills, are incorporated into L2 print information processing. Koda (2010) surmises that there are three possible ways in which L1 and L2 experience affect the formation of L2 word recognition competence. One possibility is that $\mathrm{L} 2$ processing experience has greater impact. There is no long term L1 influence on L2 processing procedures. After sufficient L2 print experience has accumulated, no L1 influence is needed. A second possibility is that L1 processing experience continues to have the greater impact. Qualitative differences stemming from L1 experience are not likely to disappear. L2 learners with dissimilar L1 backgrounds will always lag behind those with similar L1 backgrounds. A third possibility is that L2 learners from unrelated L1 backgrounds increase processing efficiency through the use of transferred L1 skills. The results systematically vary across groups with diverse backgrounds, but the distance effect on processing might not be evident. All three hypotheses have received evidence from different studies (Akamatsu, 
1999; Koda, 1990; Segalowitz \& Segalowitz, 1993), but little is known about which of the three possibilities best projects accurate pictures of longitudinal L1 and L2 impacts. The studies suggest that both $\mathrm{L}_{1}$ and $\mathrm{L}_{2}$ processing experience affect L2 word recognition development; therefore, we conducted our study to determine whether this is evident in all readers or only specific groups, i.e., lessskilled or skilled readers.

The dimension of orthographic depth (the degree to which the written system of a language corresponds to its spoken system) of Slovene language speaks in favour of the first hypothesis. Slovene has a shallow orthography with regular, i.e. transparent, symbol-sound relationships, and English orthography, in contrast, is characterized as a phonologically deep system, i.e. while governed by phonemic constraints, it tends to preserve morphological information at the expense of phonological transparency (illustrated by the past tense morpheme -ed which is pronounced in three different ways, as is talked $(/ \mathrm{t} /)$, called (/d/), visited (/id/)) (Koda, 2010). Therefore, L1 Slovene students assemble phonological information primarily through letter-by-letter, symbol-to-sound translation in their L1; however in English (L2) phonological information is obtained after a word has been identified, based on the stored knowledge of the word. Orthographic depth is directly related to the degree that phonological decoding necessitates lexical information. The decoding is dependent on particular word information retrieved from lexical memory (Koda, 2010). These memories of words (forms, patterns, sequences of letters within the words) have been referred to as orthographic images (Berninger, 1996), an aspect of orthography that is critical to accurate spelling and reading. Fluent L2 readers require in-depth knowledge of word structure as English contains many exceptions or irregular spelling patterns (e.g., once). Creating visual images is more difficult than reading words that conform to common spelling patterns (Ehri, 2000). According to this research, L1 Slovene readers must create visual images of English words because they cannot simply apply rules distinctive for their L1 to an L2. L1 Slovene readers who cannot switch to the L2/English orthographic system, i.e. individuals who do not establish visual images easily, should have more difficulty spelling and reading words. Less-skilled readers may have more difficulty in acquiring decoding accuracy in L2, as the graphophonemic regularities in L2 are not opaque. Evidence lies in research investigating English and German-speaking children with dyslexia (German is considered to be an orthographically shallow language) (Landerl, Wimmer, \& Frith, 1997). Englishspeaking children were, compared to German children, at a relative disadvantage in decoding accuracy, which can be partly explained by German language's transparent graphophonemic relationships. 
Seen as a whole, these findings indicate that $\mathrm{L} 1$ Slovene readers reading an L2 must form inter-letter associations to lead them through cumulative exposure to visual word inputs. The more frequently a letter sequence pattern is experienced, the stronger the associated connections and vice versa (Koda, 2010). Therefore, non-L2-orthographically proficient readers run the danger of not internalizing the inter-letter associations and therefore not performing efficiently in reading.

\section{Interrelationship between L2 Fluency and L2 Orthographic Skills}

We can surmise that $\mathrm{L} 2$ reading fluency (word recognition and speed) and L2 orthographic skills are interrelated. This is suggested by the definition of orthographic skills. Orthographic skills include "the ability to [...] establish detailed visual or mental representations of letter strings and words and to have rapid, fluent access to these representations" (Mather \& Goldstein, 2001, p. 165) and a number of studies among L1 English readers. Compton (2000), and Shankweiler and associates (1999) reported that early alphabetic reading (decoding) and orthographic reading (word identification) skills are highly related (0.70 and 0.90, respectively). To develop word recognition, readers must have experience seeing printed materials and have opportunities to practice reading words. Readers do not recognize words that they have not seen before in print. After several exposures to a word, a reader soon learns to associate the appearance of the word in print with its speech sound. Once this association has occurred, the reader will recognize the printed word automatically the next time he/she sees it. This ability is essential for reading fast and accurately and this ability is influenced by his/ her orthographic skills. By reading quickly, accurately and more, readers encounter more words, even exception words (e.g. island, yacht, aisle) and exposure to exception words encourages their word-specific orthographic memories, consequently establishing high-quality and high-quantity reading.

\section{The Study}

Research on the relationship between L2 fluency (word recognition and speed) and L2 orthographic skills (word identification) is scarce, in contrast to the growing body of research on L1 fluency (Rasinski, 2003) and the effects of different L1 backgrounds on L2 word recognition (Akamatsu, 1999; Koda, 2010). However, L2 reading performance relates to interrelated skills. It would be worthwhile to have more research that relates $\mathrm{L}_{1}$ reading ability and $\mathrm{L} 2$ word 
and contextual level fluency together with L2 orthography skills; skilled and less-skilled readers should be considered. Only by identifying possible reading fluency deficiencies, orthographic skills limitations or any other interactive deficiencies, can effective intervention be implemented early enough.

The present study sought to answer the following questions:

1. Do skilled L1 Slovene readers and less-skilled ones differ in L2 fluency?

2. Do skilled L1 Slovene readers and less-skilled ones differ in L2 orthographic skills?

3. Are L2 fluency and L2 orthographic skills interrelated in L1 Slovene readers?

\section{Method}

\section{Participants}

A total of 225 Grade 7 students, aged between 12 years, 6 months and 12 years, 10 months (mean age: 12 years, 8 months) participated in the study. They attended six different primary schools in Slovenia, in which Slovene was the teaching medium. They learned English as a foreign language (EFL); it is a compulsory school subject from Grade 4 to Grade 9. The English program includes listening, speaking, use of language, and reading activities. Reading instruction includes a balanced combination of decoding-oriented and meaning-based methods; English learning instruction is based on a communicative teaching approach. The Slovene school system is a public, unitary system, based on an ideology of inclusion. Primary schooling lasts from Grade 1 (age 6) to Grade 9 (age 15). Phonemic awareness, onset, rhyme and basic phonic pattern instructions for Slovene are introduced in preschool and Grade 1, whereas the initial literacy skills of reading and writing are learned in Grades 2 and 3.

A 30-passage rapid reading test (RRT) (Lipec Stopar, 1999) was prepared to measure students' reading fluency in $\mathrm{L}_{1}(\mathrm{M}=13.66, \mathrm{SD}=7.24$, test-retest reliability coefficient $\mathrm{r}=0.87$ ). The raw scores on RRT were converted to standardized $z$ scores. The students who performed above average on RRT were placed in a group of skilled readers, whereas those performing below average on RRT formed a group of less-skilled readers, while the rest comprised the medium group. The medium group was excluded from further analysis.

Statistical analyses are based on the data of those less-skilled and skilled readers who are equal on the basis of age (in years) and amount of print exposure to the English language per day in hours as determined by the information provided by a student questionnaire. $T$-tests show they are random samples from the same populations ( $\mathrm{p}>0.05)$. 
All these procedures left 195 students in the present study: 93 in the lessskilled group and 102 in the skilled group. The characteristics of the participants are summarised in Table 1.

Table 1: Characteristics of participants

\begin{tabular}{|l|l|r|r|r|r|}
\hline & Group & Min & Max & Mean & SD \\
\hline \multirow{2}{*}{ RRT result } & Less-Skilled & 0.0 & 12.0 & 6.83 & 3.92 \\
\cline { 2 - 6 } & Skilled & 15.0 & 30.0 & 19.92 & 4.20 \\
\hline \multirow{2}{*}{ Age } & Less-Skilled & 12.51 & 12.73 & 12.68 & 0.35 \\
\cline { 2 - 6 } & Skilled & 12.59 & 12.81 & 12.71 & 0.24 \\
\hline \multirow{2}{*}{ Print exposure } & Less-Skilled & 0.16 & 4.59 & 1.32 & 0.56 \\
\cline { 2 - 6 } & Skilled & 0.20 & 8.61 & 1.39 & 0.84 \\
\hline
\end{tabular}

\section{Instruments}

Rapid Reading Test in Slovene (RRT; Lipec Stopar, 1999)

The RRT measures reading ability and reading comprehension, with emphasis on the rate of reading. It consists of 30 text passages, and in every passage there is a word semantically unrelated to the rest of the text. Students were to identify the word by making a slash through it. They were given three minutes to complete as many passages as possible.

Test of Silent Word Reading Fluency (TOSWRF; Mather, Hammill, Allen, \& Roberts, 2004)

The TOSWRF was designed to measure word identification and speed (i.e., reading fluency). However, it also measures word comprehension. Because TOSWRF scores reflect competence in so many aspects of reading, the test results can be viewed as a valid estimate of general reading ability, and can be used to identify poor readers. The students were presented with a row of words, ordered by reading difficulty; no spaces appear between the words (e.g., dimhowfigblue). The students were given three minutes to draw lines between the boundaries of as many words as possible (e.g., dim/how/fig/blue/). Because there is no standardized test of silent word reading fluency in English in Slovenia, the TOSWRF was modified to the proficiency level of English of Slovene students in Grade 7. A pilot study was conducted in June 2011; 171 English words were selected arranged in ascending order of difficulty. The words at the start of the test were typically short and frequently used, whereas the words later in the test were typically longer. We investigated the test-retest reliability using a group of 52 students and the test-retest reliability coefficient was $r=0.86$. 
Test of Silent Contextual Reading Fluency (TOSCRF; Hammill, Wiederholt, \& Allen, 2006)

The TOSCRF was designed to measure the speed with which students can recognize the individual words in a series of printed passages that become progressively more difficult in their content, vocabulary, and grammar. The easy passages use beginner-level words and simple grammar; the difficult passages use advanced-level words and complex grammar (embedded sentences, sequenced adjectives, affixes, etc.). The passages were printed without punctuation or spaces between words (e.g., AYELLOWBIRDSATONMOTHERSPRETTYHAT). The students were given three minutes to draw lines between as many words as possible (e.g., A|YELLOW|BIRD|SAT|ON|MOTHERS|PRETTY|HAT). Because there is no standardized test of silent contextual reading fluency in English in Slovenia, the TOSCRF was modified to the proficiency level of English of Slovene students in Grade 7. A pilot study was conducted in June 2011; 186 English words in 15 passages were selected. We investigated the test-retest reliability using a group of 52 students and the test-retest reliability coefficient was $r=0.87$.

Test of Orthographic Competence (TOC; Mather, Roberts, Hammill, \& Allen, 2008)

The TOC was designed as an efficient, reliable, and valid measure of orthography in school-age students. Three subtests were used in the study:

- Grapheme Matching, in which students were shown a series of rows, each of which had five figures. They were to identify two identical figures in each row by making a slash through them; 45 seconds were given to complete the subtest;

- Letter Choice, in which students were shown rows of words that have one of four letters ( $\mathrm{p}, \mathrm{d}, \mathrm{b}, \mathrm{q}$ ) missing from each word (_etter, $b$ is missing). Students were given two minutes to write in the letters that would correctly complete as many words as possible;

- Sight Spelling, in which the teacher said a word while students looked at part of the word with one or more of the letters missing (know, students saw _ _ ow). They were asked to fill in the missing letter or letters (which include an irregular or unusual orthographic element) to complete the spelling of the word.

The TOC was modified to the proficiency level of English of Slovene students in Grade 7 in a pilot study in June 2011. The test-retest reliability coefficients for the first two subtests were $\mathrm{r}=0.77$ and $\mathrm{r}=0.89$; the internal consistency reliability of the Sight Spelling subtest was $\alpha=0.86$. 


\section{Procedures}

Students received instructions in $\mathrm{L}_{1} /$ Slovene at the beginning of each test. Tests were group-administered. Testing lasted 45 minutes. Data collection took place in April, May and June, 2012. The parents' or guardians' consents for a student's participation were obtained before testing.

\section{Results}

\section{Descriptive Statistics}

The means and standard deviations for TOSWRF, TOSCRF, TOC subtests are presented in Table 2. It is apparent from the results that fluency and orthographic attainment was higher for skilled group. Mean scores in Table 2 demonstrate that the number of words fluently read outside or in the context is almost the same within the two groups. Score ranges for TOSCRF, grapheme matching and sight spelling provides an interesting view that even less-skilled L1 readers can achieve same or higher score than skilled L1 readers. Regarding all the variables, all of the cases that were two or more standard deviations from the mean were considered to be extreme cases and were excluded from the subsequent analyses. A total of eight cases were eliminated.

Table 2: Mean performance on TOSWRF, TOSCRF, grapheme matching, letter choice and sight spelling by less-skilled and skilled readers $(\mathrm{N}=195)$

\begin{tabular}{|l|l|r|r|r|r|r|}
\hline \multicolumn{2}{|c|}{} & N & Mean & $\begin{array}{r}\text { Std. } \\
\text { Deviation }\end{array}$ & Min. & Max. \\
\hline \multirow{4}{*}{ Toswrf } & less-skilled & 93 & 63.58 & 28.06 & 0.00 & 115.00 \\
\cline { 2 - 8 } & skilled & 102 & 90.95 & 23.31 & 2.00 & 151.00 \\
\cline { 2 - 8 } & Total & 195 & 77.89 & 29.05 & 0.00 & 151.00 \\
\hline \multirow{4}{*}{ Toscrf } & less-skilled & 93 & 60.18 & 25.89 & 5.00 & 129.00 \\
\cline { 2 - 8 } & skilled & 102 & 91.49 & 28.31 & 5.00 & 159.00 \\
\cline { 2 - 8 } & Total & 195 & 76.55 & 31.32 & 5.00 & 159.00 \\
\hline \multirow{4}{*}{ grapheme_matching } & less-skilled & 93 & 8.50 & 3.31 & 0.00 & 24.00 \\
\cline { 2 - 8 } & skilled & 102 & 10.62 & 3.90 & 0.00 & 20.00 \\
\cline { 2 - 8 } & Total & 195 & 9.61 & 3.77 & 0.00 & 24.00 \\
\hline \multirow{3}{*}{ letter_choice } & less-skilled & 93 & 11.62 & 10.20 & 0.00 & 36.00 \\
\cline { 2 - 8 } & skilled & 102 & 21.20 & 12.52 & 0.00 & 48.00 \\
\cline { 2 - 7 } & Total & 195 & 16.63 & 12.41 & 0.00 & 48.00 \\
\hline \multirow{3}{*}{ sight_spelling } & less-skilled & 93 & 11.19 & 5.54 & 0.00 & 23.00 \\
\cline { 2 - 7 } & skilled & 102 & 15.63 & 4.45 & 1.00 & 23.00 \\
\cline { 2 - 7 } & Total & 195 & 13.51 & 5.46 & 0.00 & 23.00 \\
\hline
\end{tabular}




\section{Group Comparisons}

In order to investigate how the changes in performance with respect to L2 fluency and L2 orthographic skills related to L1 reading ability, the participants were divided into two groups (less-skilled and skilled) on the basis of the scores of the RRT. Before conducting a one-way between-group ANOVA, the following assumptions were met: The Kolmogorov-Smirnov statistics was calculated, showing that the variables were normally distributed ( $p>0.01)$; Levene's test for homogeneity determined that the scores in each group have homogeneous variance $(p>0.01)$. A one-way ANOVA revealed differences between the groups. The performance on all tests is different between less-skilled and skilled L1 readers. Table 3 summarises the results. Follow up, independent group t-tests showed that the participants in the skilled group read significantly more words than did their counterparts: $t(193)=-7.43, p<0.01, d=-27.37$. With regard to the contextually read words, the skilled group read significantly more words than the less-skilled group: $\mathrm{t}(193)=-8.03, \mathrm{p}<0.01, \mathrm{~d}=-31.30$. The performances on the tests measuring orthographic skills reveal similar findings. The less-skilled group identified fewer identical figures than the skilled group did: $t(193)=-4.07$, $\mathrm{p}<0.01, \mathrm{~d}=-\mathbf{2 . 1 2}$. They correctly completed fewer words with an appropriate letter: $\mathrm{t}(193)=-5.82, \mathrm{p}<0.01, \mathrm{~d}=-9.58$, and spelled correctly fewer words than their counterparts did: $\mathrm{t}(169)=-6.19, \mathrm{p}<0.01, \mathrm{~d}=-4.44$.

Table 3: Between-group comparisons on TOSWRF, TOSCRF, grapheme matching, letter choice and sight spelling $(\mathrm{N}=187)$

\begin{tabular}{|l|l|r|r|r|}
\hline \multirow{4}{*}{ toswrf } & & df & F & Sig. \\
\hline \multirow{5}{*}{ toscrf } & Between Groups & 1 & 55.225 & 0.000 \\
\cline { 2 - 5 } & Within Groups & 193 & & \\
\cline { 2 - 5 } & Total & 194 & & \\
\hline \multirow{3}{*}{ grapheme_matching } & Between Groups & 1 & 64.485 & 0.000 \\
\cline { 2 - 5 } & Within Groups & 193 & & \\
\cline { 2 - 5 } & Total & 194 & & \\
\hline \multirow{3}{*}{ letter_choice } & Between Groups & 1 & 16.599 & 0.000 \\
\cline { 2 - 5 } & Within Groups & 193 & & \\
\cline { 2 - 5 } & Total & 194 & & \\
\hline \multirow{5}{*}{ sight_spelling } & Between Groups & 193 & 33.896 & 0.000 \\
\cline { 2 - 5 } & Within Groups & 194 & & \\
\cline { 2 - 5 } & Total & 193 & & \\
\hline & Between Groups & 194 & & \\
\cline { 2 - 5 } & Within Groups & Total & & \\
\cline { 2 - 5 } & & & & \\
\hline
\end{tabular}


A one-way ANOVA was conducted on the word fluency and contextual fluency in order to investigate the within-subject performance changes across the two conditions. Considering all the assumptions underlying the repeated measures ANOVA, the results revealed that there were no significant main effects with fluency: $\mathrm{F}(1,194)=0.878, \mathrm{p}>0.05$.

\section{Inter-correlations}

Tables 4 through 6 show the inter-correlations among all the variables. Table 4 shows the overall results for the participants, and Tables 5 and 6 show the results for the less-skilled and skilled readers, respectively. L2 fluency and L2 orthographic variables are significantly interrelated. There is a significant positive correlation between all the variables, indicating that L2 fluency increases as L2 orthography skills increase. The correlations are higher in the group of less-skilled readers than in the group of skilled readers.

Table 4: Inter-correlations of Relevant Variables: Overall Participants $(\mathrm{N}=187)$

\begin{tabular}{|l|l|r|r|r|r|r|}
\hline & & $\begin{array}{r}\text { Word } \\
\text { Reading }\end{array}$ & $\begin{array}{r}\text { Contextual } \\
\text { Reading }\end{array}$ & $\begin{array}{r}\text { Grapheme } \\
\text { matching }\end{array}$ & $\begin{array}{r}\text { Letter } \\
\text { choice }\end{array}$ & $\begin{array}{r}\text { Sight } \\
\text { spelling }\end{array}$ \\
\hline $\begin{array}{l}\text { Word } \\
\text { Reading }\end{array}$ & Pearson Correlation & 1 & $0.784^{* *}$ & $0.413^{* *}$ & $0.458^{* *}$ & $0.671^{*}$ \\
\cline { 2 - 7 } $\begin{array}{l}\text { Contextual } \\
\text { Reading }\end{array}$ & Sig. (2-tailed) & & 0.000 & 0.000 & 0.000 & 0.000 \\
\hline & Pearson Correlation & & 1.0 & $0.427^{* *}$ & $0.489^{* *}$ & $0.644^{* *}$ \\
\hline $\begin{array}{l}\text { Grapheme } \\
\text { matching }\end{array}$ & Pearson Correlation & & & 0.000 & 0.000 & 0.000 \\
\cline { 2 - 7 } & Sig. (2-tailed) & & & 1.0 & $0.280^{* *}$ & $0.225^{* *}$ \\
\hline $\begin{array}{l}\text { Letter } \\
\text { choice }\end{array}$ & Pearson Correlation & & & & 0.000 & 0.002 \\
\cline { 2 - 7 } & Sig. (2-tailed) & & & & 1.0 & $0.462^{* *}$ \\
\hline $\begin{array}{l}\text { Sight } \\
\text { spelling }\end{array}$ & Pearson Correlation & & & & & 0.000 \\
\cline { 2 - 7 } ** Correlation is significant at the 0.01 level (2-tailed). & & & 1.0 \\
\hline
\end{tabular}

Table 5: Inter-correlations of Relevant Variables: Less-skilled Readers ( $\mathrm{N}=89)$

\begin{tabular}{|c|c|c|c|c|c|c|}
\hline & & $\begin{array}{r}\text { Word } \\
\text { Reading }\end{array}$ & $\begin{array}{r}\text { Contextual } \\
\text { Reading }\end{array}$ & $\begin{array}{r}\text { Grapheme } \\
\text { matching }\end{array}$ & $\begin{array}{l}\text { Letter } \\
\text { choice }\end{array}$ & $\begin{array}{r}\text { Sight } \\
\text { spelling }\end{array}$ \\
\hline \multirow{2}{*}{$\begin{array}{l}\text { Word } \\
\text { Reading }\end{array}$} & Pearson Correlation & 1.0 & $0.779^{* *}$ & $0.326^{*}$ & $0.286^{* *}$ & $0.632^{*}$ \\
\hline & Sig. (2-tailed) & & 0.000 & 0.001 & 0.005 & 0.000 \\
\hline \multirow{2}{*}{$\begin{array}{l}\text { Contextual } \\
\text { Reading }\end{array}$} & Pearson Correlation & & 1.0 & $0.253^{*}$ & $0.413^{* *}$ & $0.662^{* 2}$ \\
\hline & Sig. (2-tailed) & & & 0.014 & 0.000 & 0.000 \\
\hline \multirow{2}{*}{$\begin{array}{l}\text { Grapheme } \\
\text { matching }\end{array}$} & Pearson Correlation & & & 1.0 & $0.261^{\circ}$ & $0.293^{* *}$ \\
\hline & Sig. (2-tailed) & & & & 0.011 & 0.004 \\
\hline \multirow{2}{*}{$\begin{array}{l}\text { Letter } \\
\text { choice }\end{array}$} & Pearson Correlation & & & & 1.0 & $0.380^{* x}$ \\
\hline & Sig. (2-tailed) & & & & & 0.000 \\
\hline \multirow{2}{*}{$\begin{array}{l}\text { Sight } \\
\text { spelling }\end{array}$} & Pearson Correlation & & & & & 1.0 \\
\hline & Sig. (2-tailed) & & & & & \\
\hline
\end{tabular}


Table 6: Inter-correlations of Relevant Variables: Skilled Readers (N=98)

\begin{tabular}{|c|c|c|c|c|c|c|}
\hline & & $\begin{array}{r}\text { Word } \\
\text { Reading } \\
\end{array}$ & $\begin{array}{r}\text { Contextual } \\
\text { Reading } \\
\end{array}$ & $\begin{array}{r}\text { Grapheme } \\
\text { matching }\end{array}$ & $\begin{array}{r}\text { Letter } \\
\text { choice }\end{array}$ & $\begin{array}{r}\text { Sight } \\
\text { spelling }\end{array}$ \\
\hline \multirow{2}{*}{$\begin{array}{l}\text { Word } \\
\text { Reading }\end{array}$} & Pearson Correlation & 1.0 & $0.670^{* *}$ & $0.346^{*}$ & $0.398^{* *}$ & $0.545^{* *}$ \\
\hline & Sig. (2-tailed) & & 0.000 & 0.000 & 0.000 & 0.000 \\
\hline \multirow{2}{*}{$\begin{array}{l}\text { Contextual } \\
\text { Reading }\end{array}$} & Pearson Correlation & & 1.0 & $0.410^{* *}$ & $0.341^{* *}$ & $0.462^{* *}$ \\
\hline & Sig. (2-tailed) & & & 0.000 & 0.000 & 0.000 \\
\hline \multirow{2}{*}{$\begin{array}{l}\text { Grapheme } \\
\text { matching }\end{array}$} & Pearson Correlation & & & 1.0 & 0.150 & -0.030 \\
\hline & Sig. (2-tailed) & & & & 0.132 & 0.764 \\
\hline \multirow{2}{*}{$\begin{array}{l}\text { Letter } \\
\text { choice }\end{array}$} & Pearson Correlation & & & & 1.0 & $0.359^{* *}$ \\
\hline & Sig. (2-tailed) & & & & & 0.000 \\
\hline \multirow{2}{*}{$\begin{array}{l}\text { Sight } \\
\text { spelling }\end{array}$} & Pearson Correlation & & & & & 1.0 \\
\hline & Sig. (2-tailed) & & & & & \\
\hline
\end{tabular}

\section{Discussion}

This study investigated whether less-skilled and skilled L1 readers differ in L2 fluency and L2 orthographic skills performance. The one-way ANOVAs and the follow-up $t$-tests revealed that the less-skilled and the skilled group differed in both variables, thus providing the answers to the first two research questions.

On TOSWRF, less-skilled readers read in average 27 less words fluently than their counterparts did, and on TOSCRF 31 words less words in context than their counterparts did. The lack of within-group difference in fluency eliminated systematic bias attributable to the participants in less-skilled group being different from the participants in the skilled-group, and indicated that the detected differences in the L2 fluency variable significantly influence the two groups' L1 reading abilities. The results of this study confirm those of other research showing that less-skilled readers decode word-by-word so slowly that they cannot retain enough information in their working memories long enough to help themselves with text discourse in order to comprehend a connected text (Grabe, 2009). This is evident especially in the attainment on TOSCRF, where the effects of syntactic, semantic and discourse influences on fluency by the lessskilled readers did not result averagely in same or even higher scores compared to the skilled groups. Despite some of the existing research providing evidence that L2 students are able to maintain equivalent and adequate levels of comprehension when reading more slowly in the L2 (Segalowitz \& Hebert, 1990), this cannot be surmised for the present study. The participants were asked to read as accurately and quickly as possible and their reading comprehension was not measured. We can surmise that the lower number of fluently read words 
by less-skilled readers actually reflects a lack of reading fluency rather than a strategic gearing down to achieve the desired comprehension. Specifically, the research findings suggest that slower $\mathrm{L} 2$ reading rates have a negative impact on comprehension (Haynes \& Carr, 1990; Nassaji \& Geva, 1999).

The discussion so far has focused on L2 reading fluency; now we turn to the remaining important question on group differences in L2 orthography skills. From the statistically significant between-group difference in grapheme matching, the skilled readers appear to have the ability to identify more identical figures than the less-skilled readers. On average, less-skilled readers identified two fewer identical words than the skilled readers group did. The amount itself, although statistically significant, is not high; however we have to consider that the measurement time was only 45 seconds. The two groups differed in the task letter choice significantly. The four letters $b, d, p$ and $q$ share similar forms, but have different orientations, and less-skilled readers, on average, successfully completed nine fewer words than skilled readers. One interpretation could be that vocabulary knowledge had an impact on the task performance; however, the words with missing letters were highly frequent in the English language and were assumed to be taught or intuitively acquired in the EFL instruction in Slovene schools, as most of the accredited textbooks contained these words in many different contexts. The other more likely interpretation is that less-skilled readers need to learn to discriminate between the visual appearances of letters that differ only in orientation. Qualitative follow-up research showed that 35\% fewer words were correctly completed by the less-skilled group in comparison to the skilled group only due to not mastering letters and print (e.g. inverting $b$ and $d$ ). Between-group difference in sight spelling was also statistically significant. The task contained many irregular spelling patterns (e.g. enough, friend, they) with which recalling the spelling (orthographic images, (Berninger, 1996)) is necessary. Clearly, the knowledge of phonics (strategy used in participants' L1) alone will not guarantee accuracy with spelling. On average, the group of skilled readers spelled correctly four more words than the less-skilled group did. In spelling irregular words, the less-skilled group, which had on average more problems recalling images, tended to regularize the element of the word that did not conform to the L2 spelling rules. For example, the word they would be spelled as "thay", even though the word has been encountered numerous times in print. Individuals with this difficulty could encounter the same word over and over again and still not remember how to spell it (Willows \& Terepocki, 1993).

To recapitulate the main results of this study, faster and more accurate L2 word and contextual reading characterizes skilled readers, and less-skilled readers are slower and less accurate in L2 reading. The skilled readers were 
able to identify more identical words, completed more words correctly, and did better at spelling words than the less-skilled readers did. The inter-correlations between fluency and sight spelling show that these are higher in the group of less-skilled readers than in the group of skilled readers. This is likely due to the difference in their familiarity with the acceptable spelling sequences or syllabic structures of the English words. While the skilled readers relate to L2 spelling patterns but also to other variables when reading in L2, the less-skilled group relates much more to orthography rules solely. Consequently, because the latter group has problems creating visual images, these rules are not very helpful to them, but actually lead to problems in reading words. Despite the collective finding from cross-linguistic studies (Akamatsu, 1999, 2008; Koda, 2010) that L1 orthographic structure is an influential factor in how L2 words are recognized even among highly proficient $\mathrm{L} 2$ readers, the more skilled readers in the present study may have developed an L2-specific processing ability distinguishable from that of the less-skilled readers, consequently leading them to being more fluent L2 readers who demonstrate better L2 orthographic skills.

Research on the relationship between $\mathrm{L}_{1}$ reading ability and $\mathrm{L} 2$ reading components is worth expanding, and one way to pursue it is by considering the limitations of the present study. The individual and group differences in L2 reading may be accounted for by the individual differences in vocabulary knowledge, word or sub-word recognition efficiency, phonological awareness, and working memory, which overlap with general verbal comprehension skills. L2 fluency and L2 orthographic skills can explain a part of the variance in L2 reading ability. As L2 orthographic skills, in particular spelling, require not only knowledge of phonics but also in-depth knowledge of word structure, visual and working memory should be taken into account. Generalizability of the results from the present study is limited to L1 Slovene EFL students in Grade 7 of the Slovene educational system, so additional studies involving different student populations and different language combinations would be much more informative.

\section{Implications for Teaching}

Accurate and rapid word recognition, leading to reading fluency, is achieved as a result of massive exposure to words in the target language and, for that purpose, students should be encouraged to read as much as possible. As the less-skilled and skilled groups were matched for exposure to L2 in the present study, but still differed in L2 fluency and L2 orthographic skills, it can be predicted that the less-skilled readers need more suitable opportunities for 
processing words in the text while attending to their semantic contents. To develop fluency through extensive reading, recommendations have been made on how to devise exercises specifically for improving word recognition speed (Grabe \& Stoller, 2002). One of the most widely recommended exercises is one in which the student searches for the target word from among distractors as quickly as possible. According to Crawford, the majority of word recognition exercises in textbooks and articles related to L2 fluency reading resemble this exercise (Crawford, 2005). L2 text reading can be made easier for students with reading difficulties, using various forms of assisted reading (CDs, computer programs, choral reading, and partner reading). Students must be motivated to read more, also by taking into account their interests and feeding those interests through reading. Teachers can experiment with supplements to text reading such as word and sub-word study, word lists, and the proportion of time devoted to text- and word-level practice. Among the instructional strategies that have been advocated for fluency development are repeated readings (Gorsuch \& Taguchi, 2008). These can include relatively short passages (50 to 250 words) or can include poetry. Poetry is short, highly patterned, and predictable, and it contains letter patterns that can be adapted for building students' fluency (Rasinski, 2003). Finally, students' text fluency should be measured regularly to inform instructional decision making (Fuchs et al., 2001).

Familiarity with the intra-word orthographic regularities, seen in letterchoice task and sight spelling task, differentiated the skilled and less-skilled readers in the present study. Knowing orthographic regularities may be an important asset in language learning. Visual discrimination plays an important role when students face unknown words in an L2. Learning the word's form is essential for developing other types of knowledge about the word, and orthographic processing is required in learning its written form. Strategies to develop and reinforce orthographic skills can include word searches, anagrams, proofreading or strategies such as the photographic leprechaun and proof-reader's trick (Berninger \& Wolf, 2009). Thus, orthographic skills may positively contribute to word learning, fluent reading, whereas underdeveloped orthographic knowledge may hinder it. Extensive reading activities can engage students in word learning, L2 text experience and in implicit learning of orthographic regularities. A supportive classroom environment is needed for less-skilled readers; however readers' responsibility for compensating any differential functioning of any abilities needed for language learning must not be diminished. They can overcome it by investing sufficient time and effort into the process of learning an L2. 


\section{References}

Akamatsu, N. (1999). The effects of first language orthographic features on word recognition processing in English as a second language. Reading and Writing, 11(4), 381-403.

Akamatsu, N. (2008). The effects of training on automatization of word recognition in English as a foreign language. Applied Psycholinguistics, 29(2), 175-193.

Anderson, N. J. (1999). Exploring Second Language Reading: Issues and strategies. Boston: Heinle \& Heinle.

Berninger, V. W. (1996). Reading and Writing Acquisition: A developmental neuropsychological perspective. Boulder, CO: Westview Press.

Berninger, V. W., \& Wolf, B. J. (2009). Teaching Students with Dyslexia and Dysgraphia: Lessons from teaching and science. Baltimore: Paul H. Brookes.

Compton, D. L. (2000). Modeling the response of normally achieving and at-risk first-grade children to word reading instruction. Annals of Dyslexia, 50(1), 53-84.

Crawford, M. (2005). Adding variety to word recognition exercises. English Teaching Forum, 43(2), $36-41$.

Droop, M., \& Verhoeven, L. (2003). Language proficiency and reading ability in first- and secondlanguage learners. Reading Research Quarterly, 38(1), 78-103.

Ehri, L. C. (2000). Learning to read and learning to spell: Two sides of a coin. Topics in Language Disorders, 20(3), 19-36.

Fashola, O. S., Drum, P. A., Mayer, R. E., \& Kang. S. J. (1996). A cognitive theory of orthographic transitioning: Predictable errors in how Spanish-speaking children spell English words. American Educational Research Journal, 33(4), 825-843.

Favreau, M., \& Segalowitz, N. (1982). Second language reading in fluent bilinguals. Applied Psycholinguistics, 3(4), 329-341.

Fuchs, L. S., Fuchs, D. F., Hosp, M. K., \& Jenkins, J. R. (2001). Oral reading fluency as an indicator of reading competence: A theoretical, empirical, and historical analysis. Scientific Studies of Reading, 5(3), 239-256.

Fukkink, R., Hulstijn, J., \& Simis, A. (2005). Does training in second-language word recognition skills affect reading comprehension? An experimental study. The Modern Language Journal, 89(1), $54-75$.

Goodman, K. S. (1976). A psycholinguistic guessing game. In H. Singer \& R. Ruddell (Eds.), Theoretical Models and Processes of Reading (pp. 497-508). Newark, DE: International Reading Association.

Gorsuch, G., \& Taguchi, E. (2008). Repeated reading for developing reading fluency and reading comprehension: The case of EFL learners in Vietnam. System, 36(2), 253-278.

Grabe, W. (2009). Reading in a Second Language: Moving from theory to practice. New York: Cambridge University Press.

Grabe, W., \& Stoller, F. (2002). Teaching and Researching Reading. Harlow, UK: Pearson. 
Haynes, M., \& Carr, T. H. (1990). Writing system background and second language reading: A component skills analysis of English reading by native speaker-readers of Chinese. In T. H. Carr \& B. A. Levy (Eds.), Reading and its development: Component skills approaches (pp. 375-418). San Diego, CA: Academic Press.

Hoover, W. A., \& Gough, P. B. (1990). The Simple View of Reading. Reading and Writing: An Interdisciplinary Journal, 2(2), 127-160.

Koda, K. (1990). The use of L1 reading strategies in L2 reading. Studies in Second Language Acquisition, 12(4), 393-410.

Koda, K. (2010). Insights into Second Language Reading: A cross-linguistic approach. New York: Cambridge University Press.

Landerl, K., Wimmer, H., \& Frith, U. (1997). The impact of orthographic consistency on dyslexia: A

German-English comparison. Cognition, 63(3), 315-334.

Nassaji, H., \& Geva, E. (1999). The contribution of phonological and orthographic processing skills to adult ESL reading: Evidence from native speakers of Farsi. Applied Psycholinguistics, 20(2), 241-267.

Nation, I. S. P. (2009). Teaching ESL/EFL Reading and Writing. London: Routledge.

Rasinski, T. V. (2003). The Fluent Reader: Oral reading strategies for building word recognition, fluency, and comprehension. New York: Scholastic.

Segalowitz, N. (1986). Skilled reading in the second language. In J. Vaid (Ed.), Language Processing in Bilinguals: Psycholinguistic and neurological perspectives (pp. 3-19). Hillside, NJ: Erlbaum.

Segalowitz, N. (2000). Automaticity and attentional skill in fluent performance. In H. Riggenbach (Ed.), Perspectives on Fluency (pp. 200-219). Ann Arbor, MI: University of Michigan Press.

Segalowitz, N., \& Hebert, M. (1990). Phonological recoding in the first and second language reading of skilled bilinguals. Language Learning, 40(4), 503-538.

Segalowitz, N., Poulsen, C., \& Komoda, M. (1991). Lower level components of reading skill in higher level bilinguals: Implications for reading instruction. AILA Review, 8(1), 15-30.

Segalowitz, N. S., \& Segalowitz, S. J. (1993). Skilled performance, practice, and the differentiation of speed-up from automatization effects: Evidence from second language word recognition. Applied Psycholinguistics, 14(3), 369-385.

Shankweiler, D., Lundquist, E., Katz, L., Stuebing, K. K., Fletcher, J. M., Brady, S., Fowler, A., Dreyer, L. G., Marchione, K. E., Shaywitz, S. E., \& Shaywitz, B. A. (1999). Comprehension and decoding: Patterns of association in children with reading disabilities. Scientific Studies of Reading, 3(1), 69-94. Shiotsu, T. (2010). Components of L2 Reading. Cambridge: Cambridge University Press.

Stanovich, K. E. (1980). Toward an interactive-compensatory model of individual differences in the development of reading fluency. Reading Research Quarterly, 16(1), 32-71.

Stanovich, K. E. (1991). Word recognition: Changing perspectives. In R. Barr, M. L. Kamil, P.

Mosenthal, \& P. D. Pearson (Eds.), Handbook of reading research (pp. 418-452). New York: Longman. Taguchi, E., Takayasu-Maass, M., \& Gorsuch, G. (2004). Developing reading fluency in EFL: How assisted repeated reading and extensive reading affect fluency development. Reading in a Foreign Language, 16(2), 70-96. 
Verhoeven, L. (2000). Components of early second language reading and spelling. Scientific Studies of Reading, 4(4), 313-330.

Willows, D. M., \& Terepocki, M. (1993). The relation of reversal errors to reading disabilities. In D. M. Willows, R. S. Kruk, \& E. Corcos (Eds.), Visual processes in reading and reading disabilities (pp. 31-56). Hillsdale, NJ: Erlbaum.

\section{Biographical note}

Florina Erbeli is a PhD student in the Faculty of Education at University of Ljubljana, Slovenia. She has studied English and German language and literature at University of Ljubljana, University of Leipzig and University of Vienna. Her major research interests include developing strategies for improving reading fluency and reading comprehension skills with students learning English as a foreign language, in particular students with specific learning differences. She is the author of a student's book for English for special education students and of articles on reading fluency and reading competence in foreign language instruction.

Karmen Pižorn is Assistant Professor of English Language Teaching Methodology at University of Ljubljana, Faculty of Education, Slovenia. She holds a Ph.D. in English language teaching methodology (University of Ljubljana, 2003). She has taught various courses at BA, MA and $\mathrm{PhD}$ levels related to English language teaching methodology, language assessment and general English. Her research interests include all aspects of language testing, teaching foreign languages to young learners, and other issues involved in learning and teaching foreign languages in general. 